\title{
Trade in Endangered Species
}

1976 was an eventful year in the field of international trade in endangered species. The British Government was as good as its word, and not only ratified the Washington Convention in August, but implemented it as from the beginning of January 1976. This involved the setting up of a trinity of Scientific Authorities: the Nature Conservancy Council for general advice, the Royal Botanic Gardens at Kew for plants, and a Scientific Authority for Animals under the aegis of the Department of the Environment, with Professor V.C. Wynne-Edwards as Chairman and Dr Michael Brambell as ViceChairman. In addition to Dr Brambell, three other members of the Authority - Richard Fitter, Dr Corbet and Miss Grandison - are members of the FPS Council.

\section{Additions and Amendments}

The UK ratified the Convention just in time to qualify for attendance at the First Meeting of the Parties, in Berne, Switzerland, in early November, by which time 34 countries had ratified; the UK and West Germany are the only EEC members to have done so. During the year there was great activity among the signatory countries, and many additions and amendments to the Convention were submitted, by far the largest number coming from the UK. Among the most interesting and significant of these proposals was Switzerland's to add all primates to Appendix 2 and Britain's to add all Felidae, both of which were approved. In addition all rhinos and all sea turtles except those in Australia were added to Appendix 1, as was the European otter, which is particularly important to Britain.

\section{Britain's Huge Imports}

At Berne, as part of its documentation for the Conference, the UK Government submitted a report on its implementation of the Convention for the first seven months of 1976. This revealed for the first time the details of the astonishing number of licences issued for wildlife into and out of the UK $-3 \frac{1}{4}$ million reptile skins, more than 17,000 orchids of some 160 genera, and some 42,500 kilograms of ivory from Kenya and Zambia alone. The huge consumption of reptile skins by the British leather trade includes 1,153,000 lizards (the great bulk of them monitors, Varanus species, 50,000 cobras and nearly 36,000 pythons, and nearly 400,000 of the European grass snake).

The new arrangements give an insight into the trade in animal products, unlike the old 1964 Act, which covered only live animals. The last report of the Advisory Committee for this Act, for 1975, has now been published by the Department of the Environment. The Committee succeeded in keeping ape imports at a low level - four gorillas, two gibbons and a chimpanzee - but still 125,000 wretched tortoises were imported to face almost certain death in the ensuing winter. (Under the new arrangements licences to import more than 270,000 tortoises were issued. Both the tortoises and the British balance of trade would benefit if this traffic of death were stopped.) During 1975 crocodiles were added to the Act for the first time, and 66 live alligators - the American alligator is the least endangered crocodilian - were imported during the year. 
One thing nearly went wrong during 1976 , and that was the British Government's plan to pass a special law on the import of endangered species and their products instead of relying, as they have had to do since January, on existing legislative powers. The Bill fell at first a victim to political machinations showing once more how irresponsible politicians can be, even when asked to cooperate in passing wholly non-political legislation - but as we go to press it has just received the Royal Assent.

\section{Breeding Endangered Species}

\section{Paul Leyhausen}

In 1971 FPS proposed a world conference on breeding endangered species in captivity, and the first conference was held under the joint auspices of FPS and the Jersey Wildlife Preservation Trust at Jersey Zoo in 1972 (Oryx XI:5, May 1972). This proved highly successful and in response to the worldwide demand for a repeat a second conference was held in July 1976, at the London Zoo, under the joint auspices of FPS and the Zoological Society of London, which this year celebrated its 150th anniversary. In this account Dr Paul Leyhausen, of the Max Planck Institute, who is Chairman of the IUCN Cat Group, and took part in the meetings, sums up their content and importance.

While there were still - as in the first conference - a number of papers dealing with special captive breeding techniques for particular species, ranging from butterflies to manatees, the main emphasis was on the broader aspects of captive breeding, such as keeping reliably reproducing units, genetically viable populations, and their eventual reintroduction into their original habitat, which latter must be the ultimate aim of all captive breeding of species that are seriously endangered, depleted in numbers or even extinct in the wild.

The general drift of the papers dealing with these topics was a sobering-up from the euphoria of years past which considered zoos as the 'modern Noah's Ark', an awakening from the over-confidence that it would be possible to preserve any species in captivity indefinitely until such time as it became possible to reintroduce it, once its biology and habits were sufficiently well studied to enable us to develop and maintain the proper techniques.

It came as a real shock to most of the participants when they learned that the total population of Przewalski's horses in captivity, believed by many to be a triumph of captive breeding, showed a decline in fertility and longevity of individuals, and that some of the physical characteristics of the wild animals seem to be disappearing in the captive stock.

It appears that prevention of such phenomena is not simply a matter of management. Not considering for the moment the herds of wild ungulates in semi-captivity, like the blackbuck in Texas, the first difficulty is that captive breeding groups invariably have to start from comparatively small numbers, making it impossible for the available stock to harbour all the alleles of the original gene pool of natural populations of the species. Thus the genetic potential of the species is inadequately represented from the start. Then the 